\title{
Evaluation of the quality of a molded sweet biscuit enriched with okara flour
}

\author{
Avaliação da qualidade do biscoito moldado doce enriquecido com farinha de okara
}

\author{
Regina Kitagawa GRIZOTTO ${ }^{1 *}$, Cristiane Rodrigues Gomes RUFI ${ }^{2}$, Eunice Akemi YAMADA ${ }^{3}$, Eduardo VICENTE ${ }^{4}$
}

\begin{abstract}
The objective of this research was to test the addition of soymilk residue, also known as okara, to a molded sweet biscuit (MSB). The okara was provided by two soymilk producing companies whose production systems are based on hot disintegration of decorticated (company B) or non-decorticated (company A) soybeans and separation of the soymilk. Okaras A and B were dehydrated in a flash dryer and then ground to a flour ( $\leq 200 \mathrm{mesh}$ ). The okara flours showed high protein ( $\left.35 \mathrm{~g} .100 \mathrm{~g}^{-1} \mathrm{dwb}\right)$, lipid ( $\left.17 \mathrm{~g} .100 \mathrm{~g}^{-1} \mathrm{dwb}\right)$, and fiber (17 to $\left.21 \mathrm{~g} .100 \mathrm{~g}{ }^{-1} \mathrm{dwb}\right)$ contents. The water holding capacity, protein solubility, emulsifying capacity, emulsion stability and isoflavone contents found in flour A were significantly higher $(\mathrm{p} \leq 0.05)$ than in flour B. The formulation of MSB, replacing $30 \%(\mathrm{w} / \mathrm{w})$ of the wheat flour with okara flour was tested. The results of the physical measurements, brittleness and water activity of the MSB with flours A and B did not differ significantly ( $\mathrm{p} \leq 0.05)$ from those of the standard. The color, flavor and overall quality of the MSB with $30 \%$ of okara flour B did not differ significantly from those of the standard biscuit, demonstrating its potential for application in confectionery products.
\end{abstract}

Keywords: soymilk; residue; functional technological properties; isoflavones.

\section{Resumo}

O objetivo deste trabalho foi testar a adição do resíduo do leite de soja, também conhecido como okara, ao biscoito moldado doce (BMD). O okara foi fornecido por duas empresas produtoras de leite de soja, cujos sistemas de produção baseiam-se na desintegração a quente da soja com casca (empresa A) ou sem casca (empresa B) e separação do leite de soja. Os okaras A e B foram desidratados em secador flash dryer e moídos na forma de farinha ( $\leq 200 \mathrm{mesh})$. As farinhas de okara apresentaram altos teores de proteínas $(35 \mathrm{~g} .100 \mathrm{~g}-1$ b.s.), lipídios (17 g. $100 \mathrm{~g}^{-1}$ b.s.) e fibras ( $17 \mathrm{a} 21 \mathrm{~g} .100 \mathrm{~g}^{-1}$ b.s.). A farinha A apresentou resultados de capacidade de retenção de água, solubilidade da proteína $(\mathrm{SP})$, capacidade de emulsificação $(\mathrm{CE})$, estabilidade de emulsão (EE) e teor de isoflavonas, significativamente maiores ( $\mathrm{p} \leq 0,05)$ que os determinados na farinha B. As formulações do BMD, substituindo $30 \%(\mathrm{p} / \mathrm{p})$ do peso da farinha de trigo, foram testadas. Os resultados das análises físicas, fraturabilidade e atividade de água do BMD com farinhas A e B não diferiram significativamente $(\mathrm{p} \leq 0,05)$ em relação ao padrão. A cor, o sabor e a qualidade global do MSB com $30 \%$ de farinha B não diferiram significativamente $(\mathrm{p} \leq 0,05)$ em comparação ao padrão, demonstrando potencial para a aplicação em produtos de confeitaria.

Palavras-chave: leite de soja; resíduo; propriedades funcionais tecnológicas; isoflavonas.

\section{Introduction}

The soymilk production system normally employed by Brazilian companies was developed by Bourne (1970) and is based on hot disintegration of the soybeans and separation of the insoluble fraction. This system produces good quality soymilk and large volumes of residue, also known as okara. Grizotto et al. (2006) estimated that from each ton of processed soybeans around seven tons of soymilk are produced and two tons of okara. The latter contains $85 \mathrm{~g} .100 \mathrm{~g}^{-1}$ moisture (wwb, wet weight basis) and an elevated protein content $\left(40 \mathrm{~g} .100 \mathrm{~g}^{-1} \mathrm{dwb}\right.$, dry weight basis), and deteriorates rapidly if no conservation measures are taken. Various studies have shown that okara proteins are high in nutritional value, have a high protein efficiency ratio, optimum essential amino acid profiles and a high in vitro digestibility (JACKSON et al., 2001; MA et al., 1997). In addition Bowles and Demiate (2006) and Jackson et al. (2001) showed that approximately one third of the isoflavones present in the soybean remained in the okara, suggesting that it is a good, low-cost source of nutrients for human nutrition. According to Grün et al. (2001), the isoflavones are present in four chemical forms: the aglycones daidzein, genistein and glicitein; the $\beta$-glycosides daidzin, genistin and glicitin; the acetylated glycosylated derivatives 6"-O-acetyldaidzin, 6"-O-acetylgenistin and 6"-O-acetylglicitin; and the malonylated glycosylated derivatives 6"-O-malonyldaidzin, 6"-O-malonylgenistin and 6 "-O-malonylglicitin. The distribution among these different forms of isoflavones in soybean and its protein derivatives such as flours, isolates, concentrates and textured protein depends on the processing, 97 to $98 \%$ of the isoflavones being found in the esterified form (BARBOSA et al., 2006). However, there is little commercial exploitation of okara, which is normally consigned to animal feed or is incinerated in countries such as Japan and Hong-Kong (WALISZEWSKI; PARDIO; CARREON, 2002).

Recebido para publicação em 17/11/2008

Aceito para publicação em 16/5/2009 (003953)

${ }^{1}$ Fruit and Vegetable Technology Center, Food Technology Institute - ITAL, PO Box 139, CEP 13070-178, Campinas - SP, Brazil, E-mail: regina@ital.sp.gov.br

${ }^{2}$ Cereal, Chocolate, Candy and Confectionery Technology Center, Food Technology Institute - ITAL, PO Box 139, CEP 13070-178, Campinas - SP, Brazil

3 Meat Technology Center, Food Technology Institute - ITAL, PO Box 139, CEP 13070-178, Campinas - SP, Brazil

${ }^{4}$ Food Science and Quality Center, Food Technology Institute - ITAL, PO Box 139, CEP 13070-178, Campinas - SP, Brazil

${ }^{*}$ A quem a correspondência deve ser enviada 
The conservation of okara by drying in a flash dryer was investigated by Grizotto et al. (2007). These researchers showed that the drying of okara in a flash dryer was technically viable, and the okara flour obtained showed protein contents between 36.71 and $41.39 \mathrm{~g} .100 \mathrm{~g}^{-1} \mathrm{dwb}$, lipid contents between 13.19 and

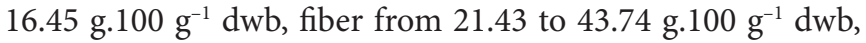
ash between 3.61 and $4.59 \mathrm{~g} .100 \mathrm{~g}^{-1} \mathrm{dwb}$ and carbohydrates varying from 38.91 to $45.01 \mathrm{~g} .100 \mathrm{~g}^{-1} \mathrm{dwb}$. According to these authors, the variation in the proximate composition is a function of the cultivar used to produce the soymilk and the process parameters. When drying okara one of the most important aspects to be considered is the preservation of the protein quality, which can be affected by the drying conditions. In addition to the nutritional aspect, one needs to know the functional technological properties of dehydrated okara, in order to evaluate its applications as a food ingredient. The term "functional technological property" when applied to a food ingredient, can be defined as all non-nutritional properties that influence the production and quality of a particular food. The majority of the functional properties influence the sensory character of the food, principally texture, but can also have an important role in the physical behavior of the foods (CHEFTEL; CUQ; LORIENT, 1989).

Various studies have focused on the use of dehydrated okara in mixtures with corn flour (TRAVAGLINI et al., 1980) and cassava flour (AGUIRRE et al., 1978) for the production of foods such as soups, corn grits and savory cassava flour. More recent studies have focused on the application of okara flour in cookies (LAROSA et al., 2006), breakfast cereals (SANTOS; BEDANI; ROSSI, 2004), tortillas (WALISZEWSKI; PARDIO; CARREON, 2002) and French-style bread (BOWLES; DEMIATE, 2006). However, none of these studies had the objective of adding okara flour into sweet molded biscuit, or of evaluating the functional technological properties of okara flour.

The objective of the present study was to evaluate the physical-chemical and functional technological properties and isoflavone content of okara flour, and also the physical, physico-chemical and sensory characteristics of the sweet molded biscuits containing 30\% of industrial okara flour in partial substitution of the wheat flour.

\section{Materials and methods}

The raw material studied was okara, provided by two Brazilian enterprises, $\mathrm{A}$ and $\mathrm{B}$, both soymilk producers located in the cities of São Paulo - SP and Pouso Alegre - MG, respectively. The system employed by the two companies for the production of soymilk was based on hot disintegration of the soybeans and separation of the insoluble fraction of the soymilk by centrifugation, as proposed by Bourne (1970), also known as the Cornell system. The difference between the industrial procedures used by the two companies resided in the fact that company B decorticated the soybeans before the disintegration step, whereas company A used the whole beans including the skin.

Eighty pounds of okara from each provider were dehydrated in a flash pneumatic dryer, also know as flash dryer, to $6 \mathrm{~g} .100 \mathrm{~g}^{-1}$ moisture, using a recirculation rate of the dried residue (RR) of $51 \%$ and a drying temperature of $280^{\circ} \mathrm{C}$, conditions established in an earlier study by Grizotto et al. (2007). After drying, the okara was ground to a flour in a blade and hammer mill (Treu \& Cia Ltda, Rio de Janeiro, Brazil) using the following sequence of sieves: $1.50,1.15,0.76$ and $0.51 \mathrm{~mm}$.

\subsection{Molded sweet biscuit production}

Samples of molded sweet biscuit (MSB) with $30 \%$ of the wheat flour replaced with okara flour A or flour B, and a standard biscuit (with no substitution), were produced following the steps of cream preparation, kneading and lamination. Table 1 show the formulations used.

Cream formation was carried out by mixing special biscuit hydrogenated vegetable fat (Maeda, Itumbiara, Brazil), refined sugar (União, Tarumã, Brazil), liquid glucose syrup at $70{ }^{\circ}$ Brix (Giovanella, São Carlos, Brazil) and powdered vanilla essence (Sigma Chemical Co, St Louis, USA) using a planetary cake mixer (Kitchen aid, St. Joseph, USA) for 10 minutes. The kneading process consisted of mixing the wheat flour, salt and okara into the cream before finally adding the bicarbonate of ammonia dissolved in a minimal amount of water, and mixing for 5 minutes at low speed to avoid gluten development. The resulting mass was laminated to a thickness of $3 \mathrm{~mm}$ and sectioned in cylindrical form. The biscuits were placed on perforated trays and baked in an oven (Perfecta Curitiba, Curitiba, Brazil), with two successive drying cycles $\left(170{ }^{\circ} \mathrm{C} / 6\right.$ minutes and $160{ }^{\circ} \mathrm{C} / 2$ minutes), giving a total of 8 minutes baking. After cooling, the biscuits were packed into double high density polyethylene bags and stored at room temperature prior to the physical and sensory evaluations.

\subsection{Determinations of the okara flour}

The following analyses were carried out on the okara flour: crude protein (AOAC, 2005), lipids by Bligh-Dyer (AOAC, 2005), total solids by difference from the numeral 100 and the moisture content (AOAC, 2005), fiber in neutral detergent

Table 1. Formulations for the preparation of molded sweet biscuits with or without (standard) the substitution of $30 \%$ of the wheat flour (w/w) with okara flours A and B.

\begin{tabular}{lcc}
\hline \multicolumn{1}{c}{ Ingredients } & $\begin{array}{c}\text { Standard biscuit } \\
\left({\mathrm{g} . \mathrm{kg}^{-1}}^{\text {product})}\right.\end{array}$ & $\begin{array}{c}\text { Biscuit with okara } \\
\text { flour }\left(\mathrm{g} \cdot \mathrm{kg}^{-1} \text { product }\right)\end{array}$ \\
\hline Wheat flour & 551.50 & 370.35 \\
Okara flour (company A or B) & 00.00 & 158.72 \\
Refined sugar & 204.06 & 195.75 \\
Inverted sugar & 27.58 & 26.45 \\
Hydrogenated vegetable fat & 148.91 & 142.85 \\
Salt & 2.76 & 2.65 \\
Ammonium bicarbonate & 1.65 & 1.59 \\
Lecithin & 3.11 & 2.98 \\
Aroma of powdered vanilla & 3.86 & 3.70 \\
Water & 56.57 & 94.96 \\
Total & 1000.00 & 1000.00 \\
\hline
\end{tabular}


(FDN) (AOAC, 2005), ash (AOAC, 2005) and carbohydrates calculated by difference $[100-$ (protein + lipid + fiber + ash + moisture)]. The granulometry was determined in a sieve shaker (Produtex, Rio de Janeiro, Brazil) using a sequence of sieves with 120, 200, 230 and 325 mesh, with opening size of 125, 75,63 and $45 \mu \mathrm{m}$, respectively. Two grams of okara flour with approximately $100 \mathrm{~mL}$ of $98 \%$ pure ethanol were put in a sieve shaker and the percentage of mass retained in each sieve after 30 minutes of shaking at maximum velocity was calculated.

The functional technological properties evaluated in the okara flours were: protein solubility (PS) as described by Morr et al. (1985), water holding capacity (WHC) according to Regenstein, Gorimar and Sherlon (1979), emulsifying capacity (EC) according to De Kanterewicz et al. (1987) and emulsion stability (ES) according to Acton and Safle (1970). These determinations were carried out in triplicate and the results expressed on a wet (wwb) or dry (dwb) weight basis, depending on the analysis. The isoflavone contents of the okara flours A and B were determined by high performance liquid chromatography (HPLC) in duplicate, and the results expressed in $\mathrm{mg}$ of isoflavones (aglycones) per $100 \mathrm{~g}$ of sample on a dwb. The different forms of isoflavones ( $\beta$-glycosides, malonylglycosides, acetylglycosides and aglycones) were expressed as a \% of the total (w/w) according to Berhow (2002).

\subsection{Determinations of the molded sweet biscuit}

The mean thickness in $\mathrm{cm}$ of a pile of five biscuits was measured using a pachymeter; the diameter in $\mathrm{cm}$ was determined from the mean of two measurements made at $0^{\circ}$ and $90^{\circ}$ using a ruler marked in millimeters, the biscuits being placed in the longitudinal position; the expansion index was calculated from the ratio between the values for diameter $(\mathrm{cm})$ and thickness $(\mathrm{cm})$ of the biscuits; the volume was calculated using the equation for a solid cylinder $\left(\pi \cdot r^{2} . h\right)$ where the height $h$ is equal to the thickness of the biscuit. The physical determinations were carried out in sextuplet, according to the methodologies described by Pizzinato et al. (1993).

Brittleness was determined using the texture analyzer (TA.XT2) and the software XTRAD Dimension from Stable Micro Systems. Ten biscuits from the same batch were selected for this analysis. The point bending rig probe $(\mathrm{HDP} / 3 \mathrm{~PB})$ was used with a $25 \mathrm{~kg}$ load cell and heavy duty platform support (HDP/90). The moisture content (AOAC, 2005) and water activity model C hygrometer - Aqualab (Decagon Devices Inc., Pullman, USA) were determined on the same biscuit samples, both with three repetitions.

The evaluation of the acceptability of the biscuits, with and without the A and B okara flours, was carried out by a team of 50 consumers (MEILGAARD; CIVILLE; CARR, 1999), who liked and regularly consumed such products. The test was carried out in individual, computerized booths, illuminated with artificial light. The software used for the preparation, filling-in and evaluation of the questionnaire was the CSA, version 4.2, from COMPUSENSE INC. - Canada (Computerized sensory analysis program). The three formulations of biscuit were presented to the judges in a monadic way, accompanied by drinking water. The judges evaluated the attributes of color, flavor, texture and overall quality using a 7 -point verbal hedonic scale $(7=$ liked immensely to $1=$ disliked immensely $)$. The buying intention was evaluated on a 5 -point scale $(5=$ certainly buy to $1=$ certainly would not buy). The sensorial evaluation received favorable opinion by the Research Ethics Committee of the Faculty of Medical Science of the State University of Campinas (UNICAMP), on 3 March 2006.

\subsection{Data analysis}

The results of the determinations carried out on the okara flours and on the molded sweet biscuits were submitted to the analysis of variance (ANOVA) using the STATISTICA PROGRAM, VERSION 6 (Statsoft. Inc., USA), and Tukey's means test was used to compare the means at a $5 \%$ significance level.

\section{Results and discussion}

Okara flours A and B presented similar values for moisture $\left(7 \mathrm{~g} .100 \mathrm{~g} \mathrm{~g}^{-1}\right)$, proteins $\left(35 \mathrm{~g} .100 \mathrm{~g}^{-1}\right)$, lipids $\left(17 \mathrm{~g} .100 \mathrm{~g}^{-1}\right)$ and ash $\left(4 \mathrm{~g} .100 \mathrm{~g}^{-1}\right)$ contents, as shown in Table 2 .

The total fiber content of the okara from company A (20.58 g.100 g $\left.\mathrm{g}^{-1}\right)$ was greater than that from company B $\left(16.12 \mathrm{~g} .100 \mathrm{~g}^{-1}\right)$, the most probable explanation being the presence of the okara skin, since company A produced the

Table 2. Results ${ }^{(1)}$ for the physical-chemical determinations and technological functional properties of the okara flours dehydrated in a flash dryer, provided by companies A and B.

\begin{tabular}{|c|c|c|}
\hline & Okara A & Okara B \\
\hline Moisture (g.100 g $\left.{ }^{-1}\right)(\mathrm{dwb})$ & $6.88 \pm 0.11^{\mathrm{a}}$ & $6.51 \pm 0.16^{b}$ \\
\hline Total solids (g.100 g $\left.\mathrm{g}^{-1}\right)(\mathrm{dwb})$ & $93.49 \pm 0.16^{\mathrm{a}}$ & $93.12 \pm 0.11^{\mathrm{b}}$ \\
\hline $\begin{array}{l}\text { Granulometry (\% retention by } \\
200 \text { mesh) }\end{array}$ & $38.87 \pm 1.10^{\mathrm{a}}$ & $30.52 \pm 0.92^{\circ}$ \\
\hline Proteins (g.100 g $\left.\mathrm{g}^{-1}\right)(\mathrm{dwb})$ & $35.36 \pm 0.91^{\mathrm{a}}$ & $34.93 \pm 1.21^{\mathrm{a}}$ \\
\hline Lipids (g.100 g $\left.{ }^{-1}\right)(\mathrm{dwb})$ & $16.71 \pm 0.15^{\mathrm{a}}$ & $17.08 \pm 0.25^{\mathrm{a}}$ \\
\hline Total fiber (g.100 g-1) (dwb) & $20.58 \pm 0.79^{\mathrm{a}}$ & $16.12 \pm 0.69^{\mathrm{b}}$ \\
\hline Ash $\left(\mathrm{g} .100 \mathrm{~g}^{-1}\right)(\mathrm{dwb})$ & $4.01 \pm 0.06^{\mathrm{a}}$ & $3.93 \pm 0.05^{\mathrm{a}}$ \\
\hline Carbohydrates (g.100 g $\left.{ }^{-1}\right)(\mathrm{dwb})$ & $16.46 \pm 0.82^{\mathrm{a}}$ & $21.44 \pm 1.19^{\mathrm{a}}$ \\
\hline WHC (g water. $\mathrm{g}^{-1}$ protein), $\mathrm{pH} 3$ & $28.33 \pm 1.87^{\mathrm{a}}$ & $22.03 \pm 0.71^{b}$ \\
\hline WHC (g water. ${ }^{-1}$ protein), pH 5 & $19.74 \pm 1.58^{\mathrm{a}}$ & $19.84 \pm 0.62^{\mathrm{a}}$ \\
\hline WHC (g water. ${ }^{-1}$ protein), $\mathrm{pH} 7$ & $22.28 \pm 1.14^{\mathrm{a}}$ & $17.10 \pm 5.41^{\mathrm{a}}$ \\
\hline $\begin{array}{l}\text { PS (g soluble protein. } 100 \mathrm{~g}^{-1} \text { material), } \\
\mathrm{pH} 3\end{array}$ & $29.98 \pm 2.00^{\mathrm{a}}$ & $25.55 \pm 0.80^{a}$ \\
\hline $\begin{array}{l}\text { PS (g soluble protein. } 100 \mathrm{~g}^{-1} \text { material), } \\
\text { pH } 5\end{array}$ & $25.17 \pm 0.00^{\mathrm{a}}$ & $21.15 \pm 0.50^{b}$ \\
\hline $\begin{array}{l}\text { PS (g soluble protein. } 100 \mathrm{~g}^{-1} \text { material), } \\
\text { pH } 7\end{array}$ & $41.29 \pm 1.20^{\mathrm{a}}$ & $29.81 \pm 1.20^{\mathrm{a}}$ \\
\hline EC (mL oil.g ${ }^{-1}$ protein $)$ & 339.4 & 89.0 \\
\hline ES (\%) & $92.56 \pm 2.64^{\mathrm{a}}$ & $38.78 \pm 5.48^{\mathrm{b}}$ \\
\hline
\end{tabular}


soymilk from non- decorticated whole soybeans. Okara flours A and B presented, respectively, 31 and $24 \%$ of particles retained on the 200 mesh sieve, corresponding to an opening of $75 \mu \mathrm{m}$, and could thus be classified as fine flour.

The water holding capacity at $\mathrm{pH} 3$ was significantly higher for okara flour A (28.33 g. $\mathrm{H}_{2} \mathrm{O} . \mathrm{g}^{-1}$ protein) than for okara flour B

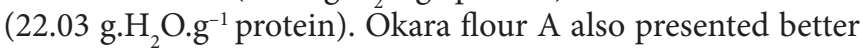
results for emulsification capacity (336 mL oil. $\mathrm{g}^{-1}$ protein), emulsion stability (92\%) and protein solubility at pH 5 (25 g soluble protein. $100 \mathrm{~g}^{-1}$ sample), significantly better $(\mathrm{p} \leq 0.05)$ than okara flour B.

In general terms, these functional technological properties translate the quality of the protein present in the material. Thus the better results obtained from flour A can be explained on the basis of the presence of the hypocotyl, since company A processed whole soybeans. The hypocotyl, also known as the hypocotyledon or germ, corresponds to only $2 \%$ of the total weight of the soybean and is found next to the skin (BOURNE, 1970), and contains an elevated protein content (40 g. $\left.100 \mathrm{~g} \mathrm{~g}^{-1}\right)$ of excellent quality and approximately 90 per cent of the total isoflavones present in the soybean. In fact, as can be seen in Table 3, the total isoflavone content determined for the flour A (133.76 mg. $\left.100 \mathrm{~g}^{-1}\right)$ was almost twice that found in flour B (78.66 mg. $100 \mathrm{~g} \mathrm{~g}^{-1}$ ) and four times the value found in the dehydrated okara (3573 mg.100 g $\mathrm{g}^{-1}$ ) as determined by Bowles and Demiate (2006). The isoflavones present in the okara flours $\mathrm{A}$ and $\mathrm{B}$ showed a predominance of the forms malonylglycosides and $\beta$-glycosides ( $\sim 90 \%$ of the total), with a profile similar to that determined by Barbosa et al. (2006) for soybeans, characterizing the okara flours as minimally processed soybean products.

Table 4 shows the results of the physical measurements (diameter, thickness, expansion index and volume), and moisture content and water activity determined on the molded sweet biscuit.

The measurement of the diameter indicates the spherical uniformity and the longitudinal growth of the biscuit. Two measurements were made for the diameter of the biscuits in the positions of $0^{\circ}$ and $90^{\circ}$, and the results obtained presented means with low standard errors $\left(\delta_{\mathrm{n}-1}\right)$. The thickness $(\mathrm{cm})$, volume $\left(\mathrm{cm}^{2}\right)$ and consequently the expansion index also did not vary significantly $(\mathrm{p} \leq 0.05)$ when compared with the standard.

Table 3. Distribution of the isoflavone forms in the okara flours A e B.

\begin{tabular}{|c|c|c|}
\hline Isoflavone forms (\%) & Okara flour A & Okara flour B \\
\hline$\beta$-glycosides & 40.04 & 20.30 \\
\hline Malonylglycosides & 49.25 & 30.57 \\
\hline Acetylglycosides & 5.48 & 4.95 \\
\hline Aglycones & 5.24 & 3.30 \\
\hline Daidzein total & 17.90 & 7.16 \\
\hline Glicitein total & 5.36 & 1.92 \\
\hline Genistein total & 22.02 & 14.52 \\
\hline Isoflavones total (mg.100 g $\left.{ }^{-1}\right)$ & 133.04 & 78.66 \\
\hline
\end{tabular}

The isoflavone forms (conjugated or aglycones) are expressed as percentages of the total (w/w).
Based on the physical measurements of the MSB, the addition of okara flour did not alter the spherical format or the longitudinal growth of the biscuits.

The biscuits with added okara flour (A and B) showed a reduced value for brittleness when compared with the standard (Table 4), which was perceived by the team of 50 judges (Table 5). The team attributed scores of 5.08 and 5.16, close to "liked slightly" for the texture of the biscuits with okara flours A and B, significantly different from the score of 5.84, close to "liked moderately", attributed to the standard biscuit.

The softer texture of the biscuits with okara flour (A or B) as compared to the standard can be explained on the basis of the interactive behavior of the different constituents of the okara flour, such as the proteins, lipids and fibers, present in high concentrations. Although the proximate compositions of the MSB with and without $30 \%$ substitution of the wheat flour with okara flour have not yet been determined, based on the compositions of wheat flour (TACO, 2006) and of okara flours A and B (Table 2), it can be estimated that the MSB formulation could present a great increase in food fiber content. It was calculated that this increase in fiber content would be around 2 and 1.5 times with the addition of flours A and B, respectively.

Table 4. Physical $^{(1)}$, physicochemical ${ }^{(2)}$ and brittleness ${ }^{(3)}$ determinations of the molded sweet biscuit produced with or without (standard) $30 \%$ substitution of the wheat flour with okara flours A or B.

\begin{tabular}{lccc}
\hline \multicolumn{1}{c}{ Determinations } & Standard & Okara A & Okara B \\
\hline Diameter $^{(1)}(\mathrm{cm})$ & $3.82 \pm 0.01^{\mathrm{a}}$ & $3.74 \pm 0.02^{\mathrm{b}}$ & $3.81 \pm 0.01^{\mathrm{a}}$ \\
Thickness $^{(1)}(\mathrm{cm})$ & $0.61 \pm 0.03^{\mathrm{a}}$ & $0.63 \pm 0.03^{\mathrm{a}}$ & $0.63 \pm 0.05^{\mathrm{a}}$ \\
Volume $^{(1)}\left(\mathrm{cm}^{3}\right)$ & $7.16 \pm 0.54^{\mathrm{a}}$ & $6.95 \pm 0.32^{\mathrm{a}}$ & $6.86 \pm 0.39^{\mathrm{a}}$ \\
Expansion index $^{(1)}$ & $6.31 \pm 0.31^{\mathrm{a}}$ & $5.97 \pm 0.25^{\mathrm{a}}$ & $6.07 \pm 0.45^{\mathrm{a}}$ \\
Moisture $\left(\mathrm{g} .100 \mathrm{~g}^{-1}\right)^{(2)}$ & $3.24 \pm 0.02^{\mathrm{a}}$ & $3.24 \pm 0.01^{\mathrm{a}}$ & $2.89 \pm 0.00^{\mathrm{b}}$ \\
Water activity $^{(2)}$ & $0.396 \pm 0.06^{\mathrm{a}}$ & $0.426 \pm 0.012^{\mathrm{b}}$ & $0.398 \pm 0.012^{\mathrm{a}}$ \\
Brittleness $^{(3)}(\mathrm{g})$ & $1.34 \pm 0.27^{\mathrm{a}}$ & $0.97 \pm 0.18^{\mathrm{b}}$ & $0.97 \pm 0.17^{\mathrm{b}}$ \\
\hline
\end{tabular}

${ }^{(1)}$ Mean of six determinations \pm standard error; ${ }^{(2)}$ mean of three determinations \pm standard error; ${ }^{(3)}$ mean of ten determinations \pm standard error in Texturometer TA-XT2; Means followed by the same letters in the same line do not differ at the level of $95 \%$ of probability

Table 5. Sensory parameters and buying intention for molded sweet biscuits produced with or without (standard) substitution of $30 \%$ of the wheat flour with okara flours A and B, as evaluated by a team of 50 judges.

\begin{tabular}{|c|c|c|c|}
\hline Sensory parameters & Standard & Company A & Company B \\
\hline Color $^{(1)}$ & $6.08^{\mathrm{a}}$ & $4.58^{\mathrm{c}}$ & $5.16^{\mathrm{b}}$ \\
\hline Flavor $^{(1)}$ & $5.72^{\mathrm{a}}$ & $4.80^{\mathrm{b}}$ & $5.22^{\mathrm{a}, \mathrm{b}}$ \\
\hline Texture $^{(1)}$ & $5.84^{\mathrm{a}}$ & $5.08^{\mathrm{b}}$ & $5.16^{\mathrm{b}}$ \\
\hline Overall quality ${ }^{(1)}$ & $5.90^{\mathrm{a}}$ & $5.18^{\mathrm{b}}$ & $5.46^{\mathrm{a}, \mathrm{b}}$ \\
\hline Buying intention $^{(2)}$ & $3.04^{\mathrm{a}}$ & $2.18^{\mathrm{b}}$ & $2.42^{\mathrm{b}}$ \\
\hline \multicolumn{4}{|c|}{$\begin{array}{l}\left({ }^{(1)} \text { Acceptance scores: } 1=\text { disliked intensely; } 2=\text { disliked moderately; } 3=\text { disliked slightly; }\right. \\
4=\text { indifferent; } 5=\text { liked slightly; } 6=\text { liked moderately; } 7=\text { liked intensely; }{ }^{(2)} \text { scores for } \\
\text { buying intention: } 1=\text { certainly not buy; } 2=\text { probably not buy; } 3=\text { maybe buy, maybe } \\
\text { not; } 4=\text { probably buy; } 5=\text { certainly buy. The same upper case letters in the same line do } \\
\text { not differ significantly }(\mathrm{p}<0.05) \text {. }\end{array}$} \\
\hline
\end{tabular}


The behavior of fiber in food products, especially its influence on food texture, is still not totally clarified. It is supposed that the components of the okara flours and of the biscuit formulation establish bonds between themselves forming compounds that compromise the crispness of the biscuits.

The formulation of MSB with okara flour, rich in proteins $\left(35 \mathrm{~g} .100 \mathrm{~g}^{-1}\right)$ and lipids $\left(17 \mathrm{~g} .100 \mathrm{~g}^{-1}\right)$ could also promote increases of around $80 \%$ in the total protein content and of $30 \%$ in the lipid content. The greater capacity of the proteins present in the okara flour A to hold water could have favored water binding and made it difficult for the water to leave during baking. In fact, greater values for final moisture content (3.24 g.100 g $\mathrm{g}^{-1}$ ) and water activity (0.426) were found for the biscuit containing okara flour A as compared to that with flour $B$. The interference of the functional technological properties on the texture of MSB confirmed the hypothesis of Cheftel, Cuq and Lorient (1989).

Thus in order to obtain crisp biscuits enriched with okara flour, one must adjust the formulation to reduce the water activity and improve the crispness of the biscuits.

The addition of okara flour A prejudiced the color and overall quality of the biscuits in comparison with the standard biscuit. In fact the biscuits presented dark spots, probably due to the presence of the brown soybean hylum in the okara flour. The presence of the skin appears to be a controversial factor, despite the fact that it considerably improves the technological quality of the protein present in the okara flour and increases the isoflavone content, but it has a negative influence on the color of the product, which contributed to a lower acceptance of the biscuit. In this case, the alternative is to add another ingredient, such as cocoa powder, for example, to mask the color of the okara flour A.

The flavor and overall quality scores attributed to the biscuits with added okara flour B and to the standard biscuit were equally accepted. About $80 \%$ of the judges attributed scores between 5 ("liked slightly") and 7 ("liked a lot") for the overall quality of the biscuit with okara flour B (Table 5). This signified that the addition of $30 \%(\mathrm{w} / \mathrm{w})$ of flour B in the formulation of MSB was considered adequate, demonstrating the potential for its application in confectionery products.

The survey of buying intention for the biscuits with added $\mathrm{A}$ and B flours (Table 5) showed that the consumers still presented a certain resistance to products containing soybean. The judges attributed means of 2.18 and 2.42 to the biscuits with flours A and B, located between "probably not buy" and "maybe buy", significantly different from the score of 3.04 for the standard biscuit, between "maybe buy, maybe not" and "probably buy". This behavior was also reported by Behrens and Da Silva (2004) which suggests, in addition to improvements in the sensory aspects of soybean based products, there is a need to advertise the benefits of consuming soybean for human health, in order to raise positive expectations in the consumers and stimulate the buying and consumption of this type of product.

\section{Conclusions}

The okara flours from companies A and B showed similar proximate compositions, whereas the functional technological properties: WHC, PS, EC and ES were significantly better for okara flour A than for B.

Processing of the non-decorticated soybeans to obtain soymilk (company A) produced okara with twice the isoflavone content as compared to the okara resulting from processing with decorticated soybeans (company B).

Substitution of part of the wheat flour $(30 \% \mathrm{w} / \mathrm{w})$ with okara flour A or B in the formulation of the molded sweet biscuit did not significantly $(\mathrm{p} \leq 0.05)$ alter the spherical form or longitudinal growth of the biscuits, as compared to the standard.

The formulation of the molded sweet biscuit in which 30 per cent $(\mathrm{w} / \mathrm{w})$ of the wheat flour was substituted by okara flour B was considered adequate. Okara flour B presents great potential for application in confectionery products.

There is a need to adjust the formulation to reduce the water activity and consequently improve the crispness of the biscuits containing okara flour A.

The survey of buying intention for the biscuits containing okara flours A and B showed that the judges still present resistance to products containing soybean.

\section{Acknowledgements}

RKG is grateful to FAPESP - Fundação de Amparo à Pesquisa do Estado de São Paulo - for their financial support.

\section{References}

ACTON, J. C.; SAFLE, R. L. Stability of oil-water emulsion 1. Effects of surface tension, level of oil, viscosity and type of meat protein. Journal Food Science, v. 35, n. 9, p. 852-855, 1970.

AGUIRRE, J. M. et al. The utilization of soybean milk residue for the protein enrichment of cassava flour. Boletim do ITAL, v. 56, p. 129-156, 1978.

AOAC Internationa. Official Methods of Analysis of AOAC International. $18^{\text {th }} \mathrm{ed}$. Maryland, 2005.

BARBOSA, A. C. L. et al. Isoflavone content and profile and antioxidant acitivity of soy and soy products. Ciência Tecnologia de Alimentos, v. 26, n. 4, p. 921-926, 2006.

BEHRENS, J. H.; Da SILVA, M. A. A. P. Consumer attitude towards soybean and related products. Ciência Tecnologia de Alimentos, v. 24, n. 3, p. 431-439, 2004.

BERHOW, M. A. Modern analytical techniques for flavonoid determination. In: BUSLIG, B. S.; MANTHEY, J. A. (Ed.). Flavonoids in the living cell. New York: Klusher Academic, 2002. p. 61-76.

BOURNE, M. C. Soybean, food technology, and improved nutrition in southern Asia. In: SEMINAR AT FORD FOUNDATION, 32. 1970, New Dehli, India. New York, USA: Ford Fundation, 1970. 20 p.

BOWLES, S.; DEMIATE, I. M. Physicochemical characterization of the soymilk byproduct - okara. Ciência Tecnologia de Alimentos, v. 26, n. 3, p. 652-659, 2006. 
CHEFTEL, J. C.; CUQ, J. L.; LORIENT, D. Proteínas alimentarias: bioquímica - propriedades funcionales, valor nutricional modificaciones químicas. Zaragoza: Acribia, 1989. 346 p.

De KANTEREWICZ, R. J. et al. Water-oil absortion index (WOAI): A simple method for predicting the emulsifying capacity of food proteins. Journal Food Science, v. 52, n. 5, p. 1381-1383, 1987.

GRIZOTTO, R. K. et al. The study the drying of the soymilk residue in a pneumatic flash dryer. In: SIMPÓSIO LATINO AMERICANO DE CIÊNCIA E TECNOLOGIA DE ALIMENTOS, 7, 2007, Campinas. Anais... Campinas: SBCTA, 2007. Summary.

GRIZOTTO, R. K. et al. A study of new soybean cultivars for the production of protein extract. In: SEMINÁRIO DE INICIAÇÃO CIENTÍfICA, 13, 2006, Campinas. Proceedings... Campinas: ITAL, 2006. Summary.

GRÜN, I. U. et al. Changes in the profile of genistein, daidzein, and their conjugates during thermal processing of tofu. Journal Agricultural Food Chemistry, v. 49, n. 6, p. 2839-2843, 2001.

JACKSON, C. J. C. et al. Effect of processing on the content and composition of isoflavones during manufacturing of soy beverage and tofu. Process Biochemistry, v. 37, n. 4, p. 1117-1123, 2001.

LAROSA, G. et al. Sensory, technological and nutritional aspects os sugar cookies with the addition of okara flour. Alimentos Nutrição, v. 17, n. 2, p. 151-157, 2006.
MA, C. Y. et al. Isolation and characterization of proteins from soymilk residue (okara). Food Research International, v. 29, n. 8, p. 799-805, 1997.

MEILGAARD, M.; CIVILLE, G. V.; CARR, B. T. Sensory evaluation techniques. $3^{\text {rd }}$ ed. London: CRC Press, 1999. 387 p.

MORR, C. V. et al. Collaborative study to develop a standardized food protein solubility procedure. Journal Food Science, v. 50, n. 6, p. $1715-1718,1985$.

PIZZINATO, A. et al. Avaliação Tecnológica de Produtos Derivados de Farinha de Trigo, Pão, Macarrão, Biscoito. Campinas: ITAL, 1993. $130 \mathrm{p}$.

REGENSTEIN, J. M.; GORIMAR, T. S.; SHERLON, J. W. Measuring the water holding capacity of natural actomyosin from chicken breast muscle in the presence of pyrophosphate and divalent cations. Journal Food Biochemistry, v. 3, n. 4, p. 205-211, 1979.

SANTOS, G. C.; BEDANI, R.; ROSSI, E. A. Utilization of soy residue (okara) in breakfast cereal development. Alimentos Nutrição, v. 15, n. 1, p. 31-34, 2004.

TACO. Tabela Brasileira de Composição de Alimentos. 2 ed. Campinas: NEPA-UNICAMP, 2006. Versão II. 113p.

TRAVAGLINI, D. A. et al. The processing of soy milk residue mixed with corn grits. Boletim ITAL, v. 17, n. 3, p. 275-296, 1980.

WALISZEWSKI, K. N.; PARDIO, V.; CARREON, E. Physicochemical and sensory properties of corn torltillas made from nixtamalized corn flour fortified with spent soymilk residue (okara). Journal Food Science, v. 67, n. 8, p. 3194-3197, 2002. 